\title{
Range-wide declines of a key Neotropical ecosystem architect, the Near Threatened white-lipped peccary Tayassu pecari
}

\author{
Mariana Altrichter, Andrew Taber, Harald Beck, Rafael Reyna-Hurtado \\ Leonidas Lizarraga, Alexine Keuroghlian and Eric W. Sanderson
}

\begin{abstract}
We report a range-wide status assessment of a key Neotropical ecosystem architect, the white-lipped peccary Tayassu pecari, categorized as Near Threatened on the IUCN Red List, using published information and unpublished data from 41 scientists in 15 range countries. We estimate that the white-lipped peccary has been extirpated in $21 \%$ of its historical range over the last 100 years, with reduced abundance and a low to medium probability of long-term survival in another $48 \%$ of its current range. We found major range declines in Argentina, Paraguay, southern Brazil, Colombia, Venezuela, north-east Brazil, Mexico and Costa Rica. This species is particularly at risk in more xeric ecosystems, especially the caatinga, cerrado and pampas. Hunting and habitat destruction are the most severe threats, although there are also unexplained sudden die-offs suggestive of disease. We evaluate our results in light of this species' important interspecific interactions and its role as an ecosystem architect. One of our recommendations is that conservation efforts should focus on landscape conservation of large, continuous and ecologically intact areas containing a mosaic of different habitat types.
\end{abstract}

Keywords Conservation planning, ecological extinction, population status, range-wide priority-setting, Tayassu pecari, white-lipped peccary, South America

This paper contains supplementary material that can be found online at http://journals.cambridge.org

Mariana Altrichter* (Corresponding author) Department of Environmental Studies, University of Redlands, Redlands, California, USA. E-mail maltrichter@prescott.edu

ANDREW TABER Center for International Forestry Research, Bogor, Indonesia

Harald Beck Department of Biological Sciences, Towson University, Townson, Maryland, USA

Rafael Reyna-Hurtado McGill University, Montreal, Canada

Leonidas Lizarraga Delegacion Regional Noroeste, Administración de Parques Nacionales, Salta Capital, Argentina

Alexine Keuroghlian Wildlife Conservation Society Brazil, Rio de Janeiro, Brazil

ERIC W. SANDERSON Wildlife Conservation Society, Global Conservation Programs, Bronx, New York USA

${ }^{*}$ Current address: Environmental Studies, Prescott College, 220 Grove Avenue, Prescott, Arizona 86301, USA

Received 22 August 2010. Revision requested 13 December 2010.

Accepted 21 February 2011. First published online 2 December 2011.

\section{Introduction}

T oss of ecological interactions of key species is an in1 creasing threat to ecosystem structure and function (Redford \& Feinsinger, 2001; Soule et al., 2003), especially given the current declines in biodiversity (Secretariat of the Convention on Biological Diversity, 2010) and ecosystem services (MEA, 2005). Loss of interactions inevitably follows extinction but may also be lost before a species becomes demographically extinct, a situation known as ecological extinction. This occurs when a species no longer interacts significantly with other species, often due to a large reduction in its abundance (Estes et al., 1989). Ecological extinction may have far-ranging consequences if a species has unique and critical ecosystem functions (Novaro et al., 2000), such as is the case with the white-lipped peccary Tayassu pecari (Cetartiodactyla, Tayassuidae).

The white-lipped peccary is a social ungulate that forms large and cohesive groups which range widely in Neotropical forests from Argentina to Mexico. The species' highly frugivorous habit and group behaviour affects plant survival, recruitment and spatial distribution through seed predation, dispersal, trampling and rooting (Beck, 2005, 2006; Desbiez et al., 2009; Keuroghlian \& Eaton, 2009). By creating and maintaining wallows, which are critical aquatic habitat for many species, the white-lipped peccary also functions as an ecosystem engineer (Beck et al., 2010). This species is also important prey for large carnivores such as puma Puma concolor and jaguar Panthera onca (Sowls, 1997; Aranda, 2002) and is widely recognized for its considerable socio-economic importance to poor forest-dwelling peoples (Bodmer et al., 1993; Sowls, 1997), providing meat, hides, cash income (Stearman, 1992) and sport (Reyna-Hurtado et al., 2010).

The loss of the white-lipped peccary has been documented from extensive areas (March, 1993; Peres, 1996; Fragoso, 1997, 1999, 2004; Cullen et al., 2000; Reyna-Hurtado \& Tanner, 2007). The species faces multiple threats across its geographical range including wide-scale habitat destruction and degradation, commercial harvesting, unsustainable levels of subsistence hunting and zoonotic diseases (probably spread from domestic livestock; Fragoso, 1997, 2004; Altrichter \& Boaglio, 2004; Herrera et al., 2008; Freitas et al., 2010). The white-lipped peccary is highly vulnerable to overexploitation and habitat fragmentation because it requires large and ecologically intact areas to maintain viable populations (March, 
1993; Keuroghlian \& Eaton, 2008b), which is especially problematic given the expanding industrial-agriculture frontier and elongating road networks across the Neotropics. The species is listed on Appendix II of CITES and classified as Near Threatened on the IUCN Red List (Reyna-Hurtado et al, 2008).

The ecological importance of the white-lipped peccary, combined with its importance to human communities, its wide geographical range, diversity of habitats and national and cultural contexts, creates a broad set of rationales for conserving the species, analogous to other large-bodied herbivores such as bison Bison bison (Sanderson et al., 2008) and elephants Loxodonta africana (Alexander, 2000; Blake \& Hedges, 2004). Conservation priorities for individual species need to be developed on a scale commensurate with that of the taxa being considered (Sanderson et al., 2002a; IUCN/SSC, 2008). Planning only within protected areas is unlikely to be sufficient when populations span a variety of habitats and land-use types beyond protected area boundaries (Sowls, 1997; Woodroffe \& Ginsberg, 1998). Landscape-scale approaches have therefore been recommended for the conservation of such wide-ranging species (IUCN/SSC, 2008; Redford et al., 2010).

A major problem confronting conservation of the whitelipped peccary is the lack of recent and reliable information on its ecology, biology and population status synthesized across its range. The last assessment was over 15 years ago (Oliver, 1993). Data are difficult to obtain because of the remoteness of much of the species' distribution, the large home ranges of peccary populations, lack of technical and management capacity, and low levels of government and international support for long-term studies. As a result, it is unclear why the white-lipped peccary has recently disappeared from vast areas (March, 1993; Peres, 1996; Fragoso, 1997, 2004; ReynaHurtado, 2007).

We therefore carried out a range-wide status assessment, starting in 2005, followed by $>3$ years of additional data acquisition and analyses. We employed the range-wide priority-setting methodology first described for jaguars (Sanderson et al., 2002b) and later applied to other species in Latin America, including the tapir Tapirus terrestris (Taber et al., 2008) and American crocodiles Crocodylus acutus (Thorbjarnarson et al., 2006), and recently adopted in part by the IUCN Species Survival Commission in its guidelines on species conservation planning (IUCN/SSC, 2008). This methodology explicitly addresses how the distribution of a species varies across national and ecological geographies, based on a synthesized assessment of status across the species' historical range. It also enables quantification of range changes over time and assessment of unknown areas. Our objectives were to: (1) update historical (c. 1900) and current distribution maps for the white-lipped peccary, (2) estimate its status across its range in terms of both political and ecological geographies, (3) identify key conservation areas for conservation action and monitoring, (4) identify and rank threats, and (5) synthesize information for conservation planning and action at national and international scales.

\section{Methods}

Forty-one researchers from 15 countries (Appendix 1) provided original survey data and expert opinion in a workshop process (described below) and subsequent contributions (Taber et al., 2008). Researchers provided the following information: (1) areas for which they had information about the species' presence and status (area of knowledge), (2) coordinates of localities where the presence or absence of the species had been documented during the last 20 years, (3) the current and historical distribution of the species within areas of knowledge, and (4) key areas for the conservation of the species (peccary conservation units; Table 1). Each locality was defined as a circle of $10-\mathrm{km}$ radius $\left(315 \mathrm{~km}^{2}\right)$. Additional points were obtained from the literature and incorporated into the database. The researchers also provided information for each locality and for peccary conservation units, including hunting pressure, deforestation, non-timber resource extraction, peccary population size and trends, herd size, land tenure, land use and effectiveness of protection. Assessments for some of these categories were subjective but because these researchers have the best information available given their experience in each area we included such information in the analysis, making qualifications as appropriate.

Of the potential geographies for analysing range information and constructing conservation priorities we used the political geography of nations and an ecologically-based approach of regional habitat types, modified from globally delineated ecoregions (Dinerstein et al., 1995) and Latin American habitat units (Anon., 1995), based on the principle that it is important to ensure the long-term survival of ecologically distinct populations of the white-lipped peccary. We identified and mapped 32 eco-geographical regions within the species' range, and six principal habitat types, by further grouping similar eco-geographical regions. Each eco-geographical region indicates the region where it is found and the predominant habitat (e.g. SE Amazon/Tropical Moist Lowland Forest).

The workshop, held on 3-9 April 2005 in Santa Cruz de la Sierra, Bolivia, brought together 25 researchers, selected to maximize geographical coverage. During the workshop we revised each data layer (area of knowledge, localities, historical and current distribution, and peccary conservation units) separately. Modifications were incorporated using georeferenced digital photographs.

Distribution polygons were classified as containing peccary populations with one of three long-term survival prospects: high (populations relatively stable, with long-term survival 
TABle 1 Definitions of geographical data types used in this study.

\begin{tabular}{|c|c|c|c|}
\hline Data & Definition & Type of data & Information source \\
\hline Historical distribution & $\begin{array}{l}\text { Area where species was found c. } 100 \text { years } \\
\text { ago (1900). Altitudinal range } 0-2,000 \mathrm{~m} \text {. }\end{array}$ & Polygon & $\begin{array}{l}\text { Redford \& Eisenberg (1992), } \\
\text { Eisenberg \& Redford (2000), } \\
\text { Parera \& Erize (2002) }\end{array}$ \\
\hline Eco-geographical regions & $\begin{array}{l}\text { Regional habitat types within historical } \\
\text { distribution }\end{array}$ & Polygon & $\begin{array}{l}\text { Anon. (1995), Dinerstein et al. } \\
\text { (1995) }\end{array}$ \\
\hline Area of knowledge & $\begin{array}{l}\text { Area for which participant researchers } \\
\text { provided information on species }\end{array}$ & Polygon & This article \\
\hline Area without information & $\begin{array}{l}\text { Area for which information was not available } \\
\text { during workshop }\end{array}$ & Polygon & This article \\
\hline Current distribution & $\begin{array}{l}\text { Area where species' presence during previous } \\
20 \text { years was confirmed }\end{array}$ & Polygon & This article \\
\hline Extinct & $\begin{array}{l}\text { Area where species has disappeared within } \\
\text { previous } 20 \text { years }\end{array}$ & Polygon & This article \\
\hline Conservation units & $\begin{array}{l}\text { Areas that have or could have a self-sustaining } \\
\text { population based on area of habitat \& quality } \\
\text { of food resources (see text for details) }\end{array}$ & Polygon & This article \\
\hline Data points & $\begin{array}{l}\text { Locality points where presence or absence of } \\
\text { species was confirmed for } 1985-2005 \text {. } \\
\text { Each point represents one or more records } \\
\text { within a circle of } 10-\mathrm{km} \text { radius. }\end{array}$ & Point & This article \\
\hline
\end{tabular}

likely in a large portion of the polygon; polygons $>1,000 \mathrm{~km}^{2}$ ); medium (most populations decreasing with their viability threatened by landscape transformation and/or other human activities); low (populations small and isolated, for the most part persisting in scarce habitat fragments). We also estimated the area of each distribution polygon where the species was subject to various threats and then totalled this information across the whole range.

Peccary conservation units were defined as 'an area currently known or believed to contain a resident population of peccaries large enough to be potentially self-sustaining over the next 100 years, or an area containing fewer peccaries currently but with adequate habitat and a stable and diverse food base, such that the population could increase if threats were alleviated'. We identified the most relevant factors affecting peccary survival and qualitatively assessed their intensity within each peccary conservation unit by classifying it using a Likert scale as high, medium, none, or no information available. Experts were asked to assess each threat in each peccary conservation unit in terms of its intensity and the breadth of its geographical distribution; these data were then summarized at the range-wide level. Peccary conservation units were weighted according to the following algorithm: peccary conservation unit size was considered most important (weight $=31$ ), followed by habitat destruction (25), hunting (20), disease (10), habitat quality (6), connectivity (4), and lack of resources (4).

During the workshop, participants assigned each factor a relative weighting such that their sum equalled 10o. The intensity previously assigned to each factor was multiplied by the weight of that factor, and the resulting number was used to estimate the relative conservation status of each peccary conservation unit (Taber et al., 2008). This provided a continuum of estimators for conservation status, from poor to excellent, representing the combination of the weight of diverse factors important for the species' survival within peccary conservation units. We later grouped peccary conservation units into low, medium, and high conservation status.

\section{Results}

\section{Area of knowledge and data points}

A total of 936 localities containing 6,378 detection records of the white-lipped peccary for 1985-2005, in combination with researchers' knowledge, were used to map the current distribution of the species. At the time of the workshop we did not have any peccary locality data for French Guiana, Panama and Surinam. Large ecological areas for which we lack status information are the lowland rainforest of the Chocó-Darién and Central America $\left(79,692 \mathrm{~km}^{2}, 12 \%\right.$ of the combined area of both eco-geographical regions). Status information was also lacking for approximately half the Amazonian mangroves $\left(14,670 \mathrm{~km}^{2}, 56 \%\right.$ of the eco-geographical region; Table 2$)$.

\section{Distribution and conservation status}

We estimate that the historical range of the white-lipped peccary was $14,220,461 \mathrm{~km}^{2}$, encompassing 32 eco-geographical regions (Appendix 2; Table 2) in six principal habitat types (Appendix 3; Table 3). The current distribution extends over $11,177,435 \mathrm{~km}^{2}$ (79\% of the historical range; Fig. 1; Table 2). The largest eco-geographical region polygons are in the upper Amazon, cerrado and north-east and south-east 
TABLE 2 For each eco-geographical region (see text for details) the area of historical range, area (and percentage) in which the whitelipped peccary Tayassu peccari is extinct, for which there is no status information and of the current range, percentage of current range in which the species is considered to have high, medium and low probabilities of long-term survival, and area (and percentage) of peccary conservation units.

\begin{tabular}{|c|c|c|c|c|c|c|c|c|}
\hline \multirow{2}{*}{$\begin{array}{l}\text { Eco-geographical } \\
\text { region }\end{array}$} & \multirow{2}{*}{$\begin{array}{l}\text { Historical } \\
\text { range } \\
\left(\mathrm{km}^{2}\right)\end{array}$} & \multicolumn{3}{|c|}{ Range assessment, $\mathrm{km}^{2}(\%)$} & \multicolumn{3}{|c|}{ Survival probability (\%) } & \multirow{2}{*}{$\begin{array}{l}\text { Peccary } \\
\text { conservation } \\
\text { unit, } \mathrm{km}^{2}(\%)\end{array}$} \\
\hline & & Extinct & No info. & Current & High & Medium & Low & \\
\hline $\begin{array}{r}\text { Upper Amazon/Tropical } \\
\text { Moist Lowland Forest }\end{array}$ & $2,962,615$ & $30,870(1)$ & 0 & $2,931,745(99)$ & 79 & 21 & 0 & $1,881,608(64)$ \\
\hline $\begin{array}{l}\text { Atlantic/Tropical Moist } \\
\text { Lowland Forest }\end{array}$ & 949,837 & $105,576(11)$ & 0 & $844,26(89)$ & 5 & 4 & 91 & $59,197(7)$ \\
\hline $\begin{array}{l}\text { NE Amazon/Tropical Moist } \\
\text { Lowland Forest }\end{array}$ & $1,515,831$ & $35,733(2)$ & $1,300(0)$ & $1,478,799(98)$ & 79 & 20 & 0 & $1,233,678(83)$ \\
\hline $\begin{array}{l}\text { SE Amazon/Tropical Moist } \\
\text { Lowland Forest }\end{array}$ & $1,355,333$ & $13,849(1)$ & $5,826(0)$ & $1,335,658(99)$ & 31 & 56 & 13 & $389,073(29)$ \\
\hline $\begin{array}{l}\text { Chocó-Darién/Tropical Moist } \\
\text { Lowland Forest }\end{array}$ & 220,527 & $125,172(57)$ & $40,551(18)$ & $54,804(25)$ & 8 & 92 & 0 & $50,261(92)$ \\
\hline $\begin{array}{l}\text { Brazilian Araucaria/Tropical Moist } \\
\text { Lowland Forest }\end{array}$ & 220,916 & $71,162(32)$ & 0 & $149,755(68)$ & 5 & 7 & 88 & $11,691(8)$ \\
\hline Subtropical Andean Forest & 82,402 & $49,268(60)$ & 0 & $33,123(40)$ & 71 & 1 & 28 & $9,600(29)$ \\
\hline $\begin{array}{l}\text { Tropical Andes/Tropical } \\
\text { Moist Montane Forest }\end{array}$ & 315,790 & $129,059(41)$ & $259(0)$ & $186,473(59)$ & 80 & 16 & 4 & $77,412(42)$ \\
\hline $\begin{array}{l}\text { Guyana Montane Forest/Tropical } \\
\text { Moist Montane Forest }\end{array}$ & 333,373 & $6,906(2)$ & 0 & $326,467(98)$ & 97 & 3 & 0 & $326,174(100)$ \\
\hline $\begin{array}{l}\text { Venezuelan Coastal Montane } \\
\text { Forest/Tropical } \\
\text { Moist Montane Forest }\end{array}$ & 14,296 & $3,707(26)$ & 0 & $10,589(74)$ & 0 & 0 & 100 & 0 \\
\hline Western Andes/Tropical Dry Forest & 40,359 & $30,963(77)$ & $12(0)$ & $9,383(23)$ & 100 & 0 & 0 & 0 \\
\hline Cerrado/Tropical Dry Forest & $2,284,304$ & $62,642(3)$ & 0 & $2,221,663(97)$ & 21 & 11 & 68 & $406,043(18)$ \\
\hline Chaco/Tropical Dry Forest & 607,309 & 223,498 & 0 & $383,811(63)$ & 69 & 19 & 12 & $221,545(58)$ \\
\hline N South America/Tropical Dry Forest & 119,486 & $74,668(62)$ & 0 & $44,817(38)$ & 25 & 20 & 55 & $7,426(17)$ \\
\hline Caribbean/Xeric Forest & 97,289 & $61,207(63)$ & 0 & $36,082(37)$ & 0 & 6 & 93 & 0 \\
\hline Caatinga/Xeric Forest & 758,961 & $738,820(97)$ & 0 & $20,141(3)$ & 95 & 0 & 5 & $19,074(95)$ \\
\hline $\begin{array}{l}\text { Pantanal-Humid Chaco/Seasonally } \\
\text { Flooded Savannah Grassland }\end{array}$ & 503,442 & $152,038(30)$ & 0 & $351,403(70)$ & 60 & 13 & 28 & $215,012(61)$ \\
\hline $\begin{array}{l}\text { Llanos-Gran Sabana/Herbaceous } \\
\text { Lowland Grassland }\end{array}$ & 491,927 & $268,674(55)$ & $78(0)$ & $223,175(45)$ & 53 & 37 & 10 & $170,114(76)$ \\
\hline $\begin{array}{l}\text { Pampas/Herbaceous } \\
\text { Lowland Grassland }\end{array}$ & 242,288 & $241,405(100)$ & 0 & $883(0)$ & 0 & 0 & 100 & 0 \\
\hline $\begin{array}{l}\text { Amazonian Savannah/Herbaceous } \\
\text { Lowland Grassland }\end{array}$ & 157,402 & $274(0)$ & $2,234(1)$ & $154,893(98)$ & 72 & 28 & 0 & $86,458(56)$ \\
\hline $\begin{array}{l}\text { Beni Savannah/Herbaceous } \\
\text { Lowland Grassland }\end{array}$ & 127,119 & 0 & 0 & $127,119(100)$ & 91 & 9 & 0 & $94,368(74)$ \\
\hline $\begin{array}{l}\text { Pantepui/Herbaceous } \\
\text { Montane Grassland }\end{array}$ & 37,531 & 0 & 0 & $37,531(100)$ & 98 & 2 & 0 & $37,531(100)$ \\
\hline Amazonia/Mangrove & 26,341 & $6,501(25)$ & $14,670(56)$ & $5,170(20)$ & 75 & 25 & 0 & $3,755(73)$ \\
\hline E South America/Mangrove & 8,477 & $3,580(42)$ & $7(0)$ & $4,891(58)$ & 16 & 0 & 84 & $1,290(26)$ \\
\hline N South America/Mangrove & 11,090 & $4,476(40)$ & $3,465(31)$ & $3,149(28)$ & 0 & 75 & 25 & $1,482(47)$ \\
\hline $\begin{array}{l}\text { Central America/Tropical } \\
\text { Moist Lowland Forest }\end{array}$ & 434,279 & $230,636(53)$ & $39,141(9)$ & $164,502(38)$ & 40 & 48 & 11 & $75,566(46)$ \\
\hline $\begin{array}{l}\text { Central America/Tropical } \\
\text { Moist Montane Forest }\end{array}$ & 126,631 & $111,641(88)$ & $5,646(4)$ & $9,344(7)$ & 17 & 12 & 71 & $2,946(32)$ \\
\hline Mexican Pine-Oak/Temperate Forest & 1,363 & $1,031(76)$ & 0 & $333(24)$ & 93 & 0 & 7 & $310(93)$ \\
\hline Central America/Tropical Dry Forest & 52,107 & $46,224(89)$ & $5,118(10)$ & $765(1)$ & 100 & 0 & 0 & 0 \\
\hline Mexico/Tropical Dry Forest & 72,295 & $72,011(100)$ & 0 & $285(0)$ & 100 & 0 & 0 & $285(100)$ \\
\hline $\begin{array}{l}\text { Central American Pine } \\
\text { Savannah/Herbaceous } \\
\text { Lowland Grassland }\end{array}$ & 18,311 & 0 & 0 & $18,311(100)$ & 17 & 83 & 0 & $4,835(26)$ \\
\hline Central America/Mangrove & 31,229 & $18,670(60)$ & $4,428(14)$ & $8,111(26)$ & 39 & 53 & 8 & $3,669(45)$ \\
\hline Total & $14,220,4612$ & $2,920,260(21)$ & $122,734(1)$ & $11,177,435(79)$ & 53 & 22 & 26 & $5,390,403(48)$ \\
\hline
\end{tabular}


TABLE 3 For each principal habitat type (see text for details) the area of historical range, area (and percentage) in which the white-lipped peccary is extinct, for which there is no status information and of the current range, percentage of current range in which the species is considered to have high, medium and low probabilities of long-term survival, and area (and percentage) of peccary conservation units.

\begin{tabular}{|c|c|c|c|c|c|c|c|c|}
\hline \multirow[b]{2}{*}{ Principal habitat type } & \multirow{2}{*}{$\begin{array}{l}\text { Historical } \\
\text { range }\left(\mathrm{km}^{2}\right)\end{array}$} & \multicolumn{3}{|c|}{ Range assessment, $\mathrm{km}^{2}(\%)$} & \multicolumn{3}{|c|}{ Survival probability (\%) } & \multirow{2}{*}{$\begin{array}{l}\text { Peccary } \\
\text { conservation } \\
\text { unit, } \mathrm{km}^{2}(\%)\end{array}$} \\
\hline & & Extinct & No info. & Current & High & Medium & Low & \\
\hline $\begin{array}{l}\text { Tropical \& Subtropical } \\
\text { Moist Broad-leaf } \\
\text { Forests }\end{array}$ & $7,659,338$ & $612,997(8)$ & $86,818(1)$ & $6,959,523(91)$ & 58 & 26 & 16 & $3,701,075(53)$ \\
\hline $\begin{array}{l}\text { Tropical \& Subtropical } \\
\text { Moist to Seasonally } \\
\text { Moist Montane } \\
\text { Forests }\end{array}$ & 873,855 & $301,611(35)$ & $5,904(1)$ & $566,329(65)$ & 87 & 7 & 6 & $416,441(74)$ \\
\hline $\begin{array}{l}\text { Tropical \& Subtropical } \\
\text { Dry Forests, Savannahs } \\
\text { \& Shrublands }\end{array}$ & $4,032,110$ & $1,310,033(32)$ & $5,131(0)$ & $2,716,946(67)$ & 28 & 12 & 59 & $654,371(24)$ \\
\hline $\begin{array}{l}\text { Tropical \& Subtropical } \\
\text { Seasonally Moist } \\
\text { Grasslands \& Savannahs }\end{array}$ & $1,540,490$ & $662,392(43)$ & $2,312(0)$ & $875,785(57)$ & 64 & 22 & 14 & $570,788(65)$ \\
\hline Montane Grasslands & 37,531 & $0(0)$ & $0(0)$ & $37,531(100)$ & 98 & 2 & 0 & $37,531(100)$ \\
\hline Mangrove & 77,136 & $33,227(43)$ & $22,569(29)$ & $21,320(28)$ & 37 & 37 & 26 & $10,197(48)$ \\
\hline
\end{tabular}

Amazon (Table 2). The largest principal habitat type is the Tropical and Subtropical Moist Broad-leaf Forest (Table 3), covering $62 \%$ of the current range. Brazil contains the largest range of the species (Table 4), comprising $66 \%$ of the total distribution. The largest percentage reductions in the species' range have occurred in Central America, north-west South America, the arid regions of north-east Brazil and the fringe of the species' southern range in Argentina and Brazil. In terms of total area lost, the largest reductions have occurred in the caatinga. The current range remains essentially intact in the Central American/Herbaceous Lowland Grassland, the Beni Savannah/Herbaceous Lowland Grassland, and the Pantepui/Herbaceous Montane Grassland eco-geographical regions (Table 2). In the principal habitat types the largest reduction has occurred in the Tropical and Subtropical Dry Forests, Savannahs and Shrublands and, in percentage terms, in the Mangroves (Table 3).

By country, the largest reduction in range area has occurred in Brazil, in 13\% of the historical distribution of the species. The species has disappeared from all or a majority of its historical range in El Salvador (extinct), Costa Rica (89\%), Guatemala and Mexico (84\%) and Argentina (63\%; Table 4).

The largest eco-geographical regions containing peccary populations with high probabilities of long-term survival are the Upper and North-east Amazon/Tropical Moist Lowland Forests (c. $79 \%$ of each region's total area). The Cerrado/Tropical Dry Forest has the largest area containing small, fragmented, and isolated peccary populations with low survival probabilities. The Atlantic/ Tropical Moist Lowland Forest also has large extensions containing populations with low survival probabilities (Fig. 1; Table 2).
The Tropical and Subtropical Moist Broad-leaf Forests is the principal habitat type with the largest absolute and percentage $(53 \%)$ of its area considered to have peccary populations with high survival probabilities. The Tropical and Subtropical Dry Forests, Savannahs and Shrublands have the largest area comprising populations with low probabilities of survival (Table 3). Brazil has the largest area containing populations with high and medium probabilities of survival. However, 2.6 million $\mathrm{km}^{2}$ of the peccary distribution in Brazil contains populations with low survival probabilities. Peru and Bolivia have the largest percentage of the peccary distribution with high survival probabilities (100 and 88\% respectively). Belize and Costa Rica each contain $<10,000 \mathrm{~km}^{2}$ with populations with high survival probabilities. In Nicaragua only $16 \%$ of the current peccary range contains populations with high survival probabilities.

The two major threats to the white-lipped peccary are deforestation and habitat transformation, affecting $40 \%$ of its range. Hunting and human population growth have each affected c. $30 \%$ of the peccary distribution. Only $1 \%$ of the total range is considered to be unaffected by human activities (Table 5). These estimates reflect the area affected but not the intensity of the various threats.

\section{Peccary conservation units}

We mapped 57 peccary conservation units covering 5,390,403 $\mathrm{km}^{2}$, (48\% of the species' current distribution; Table 6; Fig. 1). A larger number of units were classified as medium $(n=26)$ than as high $(\mathrm{n}=19)$ or low $(\mathrm{n}=8)$ conservation status but $65 \%$ of the total area assigned to the units was classified as being of high conservation status. The status of four small peccary conservation units could not be classified. 


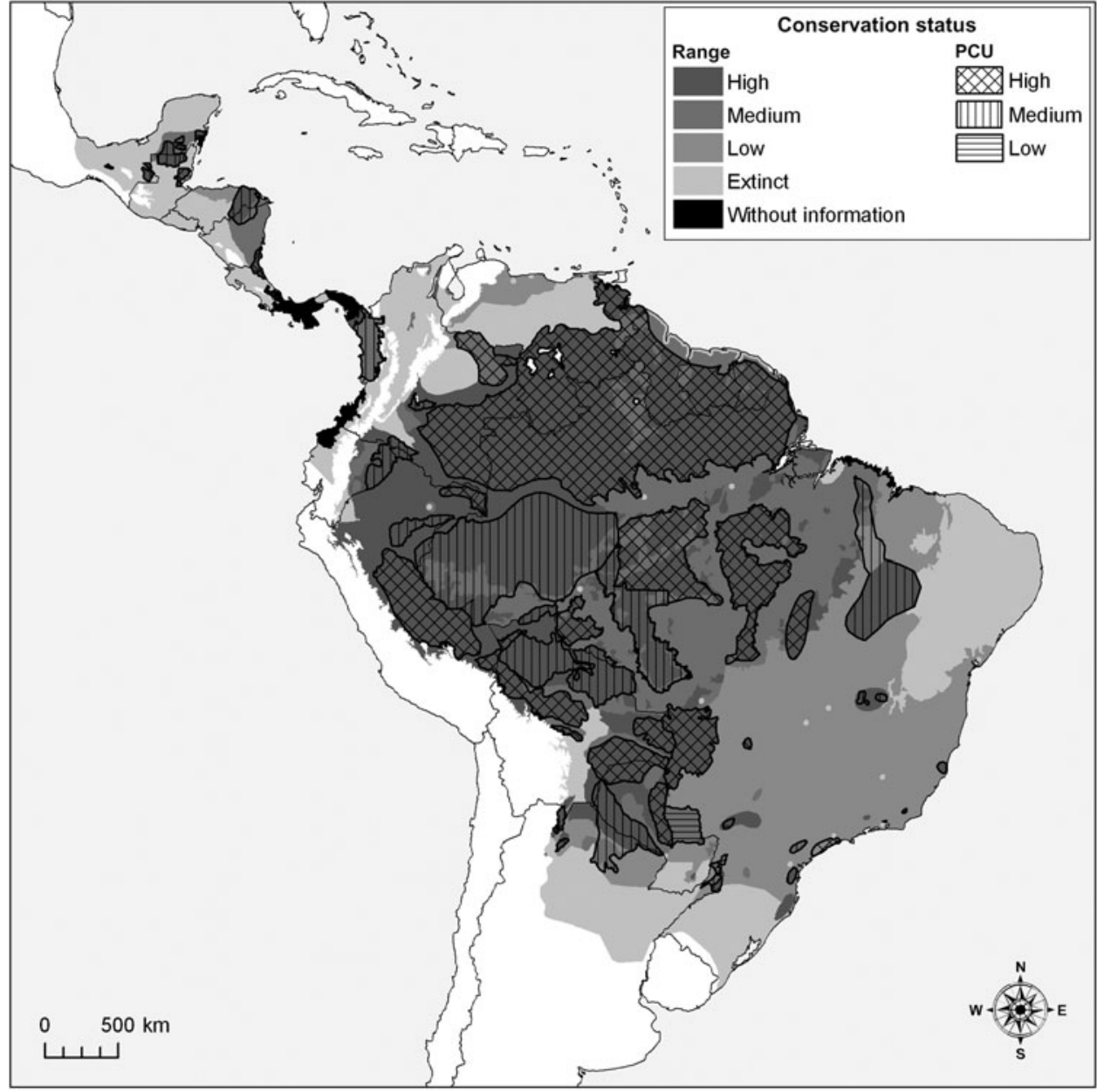

FIG. 1 Assessment of the white-lipped peccary Tayassu pecari range and conservation units (PCUs; see text for definition) as of high, medium or low conservation status (see text for details), and areas of the historical range where the species is now extinct or for which there is no information.
Peccary conservation units varied in size from $119 \mathrm{~km}^{2}$ to $>2$ million $\mathrm{km}^{2}$. The largest units are in central and northern South America and the smallest in Central America and south-eastern Brazil. The Upper and North-eastern Amazon/ Tropical Moist Lowland Forests has almost 2 million and 1.3 million $\mathrm{km}^{2}$, respectively, designated as conservation units (Table 2). All other eco-geographical regions contained $<500,000 \mathrm{~km}^{2}$ in peccary conservation units. The greatest number of units, and the largest total area designated as units (68\% of total), are in the Tropical and Subtropical Moist Broad-leaf Forests principal habitat type (Table 3 ). Brazil had the largest area designated as peccary conservation units $\left(3,064,819 \mathrm{~km}^{2}\right.$; Table 4$)$, larger than all other units combined. Bolivia, Venezuela, and Colombia also have large areas designated as peccary conservation units (c. $400,000 \mathrm{~km}^{2}$ each), whereas Belize, Costa Rica, and Panama each have $<10,000 \mathrm{~km}^{2}$ of peccary conservation units.

Peccary herd sizes were estimated to be $>20$ in $49 \%$ of the peccary conservation units. In about half of the total peccary conservation unit area the units were considered to contain populations of $>5,000$. However, in $33 \%$ of units peccary population sizes were estimated to be $1,000-5,000$
(Table 7). There was a relationship between peccary conservation unit size and the estimated peccary population: the mean peccary conservation unit size $\left(248,769 \mathrm{~km}^{2}\right)$ with $>5,000$ peccaries was 100 times larger than the mean peccary conservation unit size with $<500$ individuals. A similar relationship was observed between herd and peccary conservation unit sizes: the mean peccary conservation unit size $\left(155,424 \mathrm{~km}^{2}\right)$ with herds of $>20$ individuals was 40 times larger than the mean peccary conservation unit size with smaller herds. Almost $70 \%$ of the total peccary conservation unit area was considered to contain stable peccary populations. However, only one peccary conservation unit $(0.1 \%$ of the combined area of all peccary conservation units; Table 8) was considered to have a population that is increasing.

A larger number of peccary conservation units had medium rather than high or low levels of hunting (Table 9). Subsistence and opportunistic hunting pressure, respectively, were considered high in 28 and $16 \%$ of the units. Only two units were unaffected by subsistence hunting. Sport hunting was less prevalent. Approximately a third of the units had medium levels of deforestation pressure, whereas only $5 \%$ were unaffected by deforestation. Slightly 
TABLE 4 For each range country the area of historical range, area (and percentage) in which the white-lipped peccary is extinct, for which there is no status information and of the current range, percentage of current range in which the species is considered to have high, medium and low probabilities of long-term survival, and area (and percentage) of peccary conservation units.

\begin{tabular}{|c|c|c|c|c|c|c|c|c|}
\hline \multirow[b]{2}{*}{ Country } & \multirow{2}{*}{$\begin{array}{l}\text { Historical } \\
\text { range }\left(\mathrm{km}^{2}\right)\end{array}$} & \multicolumn{3}{|c|}{ Range assessment, $\mathrm{km}^{2}(\%)$} & \multicolumn{3}{|c|}{ Survival probability (\%) } & \multirow{2}{*}{$\begin{array}{l}\text { Peccary } \\
\text { conservation } \\
\text { unit, } \mathrm{km}^{2}(\%)\end{array}$} \\
\hline & & Extinct & No info. & Current & High & Medium & Low & \\
\hline$\overline{\text { Argentina }}$ & 679,610 & $430,186(63)$ & 0 & $249,423(37)$ & 26 & 17 & 57 & $82,785(33)$ \\
\hline Bolivia & 793,343 & $88,367(11)$ & 0 & $704,975(89)$ & 88 & 12 & 0 & $466,23(66)$ \\
\hline Brazil & $8,455,977$ & $1,095,666(13)$ & $24,114(0)$ & $7,336,197(87)$ & 41 & 24 & 35 & $3,064,819(42)$ \\
\hline Colombia & $1,005,098$ & $383,756(38)$ & $19,395(2)$ & $601,946(60)$ & 75 & 24 & 1 & $393,417(65)$ \\
\hline Ecuador & 148,934 & $46,306(31)$ & $15,821(11)$ & $86,807(58)$ & 66 & 34 & 0 & $34,540(40)$ \\
\hline French Guiana & 82,526 & $5,543(7)$ & 0 & $76,982(93)$ & 75 & 25 & 0 & $68,177(89)$ \\
\hline Guyana & 211,508 & $12,240(6)$ & 0 & $199,268(94)$ & 75 & 25 & 0 & $171,654(86)$ \\
\hline Paraguay & 399,757 & $55,677(14)$ & 0 & $344,081(86)$ & 56 & 29 & 15 & $194,722(57)$ \\
\hline Peru & 744,209 & $13,599(2)$ & 0 & $730,610(98)$ & 100 & 0 & 0 & $320,328(44)$ \\
\hline Surinam & 145,626 & $10,434(7)$ & 0 & $135,192(93)$ & 63 & 37 & 0 & $103,385(76)$ \\
\hline Venezuela & 805,578 & $298,158(37)$ & 0 & $507,42(63)$ & 77 & 5 & 18 & $403,960(80)$ \\
\hline Belize & 21,798 & $12,531(57)$ & 0 & $9,268(43)$ & 91 & 2 & 8 & $8,396(91)$ \\
\hline Costa Rica & 48,272 & $43,057(89)$ & 0 & $5,216(11)$ & 69 & 14 & 18 & $3,797(73)$ \\
\hline El Salvador & 20,644 & $20,646(100)$ & 0 & 0 & & & & \\
\hline Guatemala & 97,524 & $82,303(84)$ & 0 & $15,222(16)$ & 81 & 14 & 5 & $12,322(81)$ \\
\hline Honduras & 112,462 & $63,162(56)$ & 0 & $49,300(44)$ & 44 & 12 & 44 & $23,317(47)$ \\
\hline Mexico & 255,569 & $213,544(84)$ & $2,221(1)$ & $39,804(16)$ & 39 & 61 & 0 & $18,205(46)$ \\
\hline Nicaragua & 119,225 & $40,565(34)$ & 0 & $78,660(66)$ & 16 & 84 & 0 & $18,860(24)$ \\
\hline Panama & 72,702 & $4,405(6)$ & $61,183(84)$ & $7,114(10)$ & 79 & 0 & 21 & $1,490(21)$ \\
\hline
\end{tabular}

more than half of the units (58\%) had medium levels of extraction of natural resources (Table 10). More of the land area in peccary conservation units $(32 \%)$ was under common property than other tenure regimes and c. $30 \%$ of the total peccary conservation unit area was protected as of 2005 under one of the IUCN (1994) protected area categories (Table 11). About $60 \%$ of the total peccary conservation units have partial protection, principally on common property lands. However, only $9 \%$ of the combined peccary conservation unit area was considered to provide effective protection despite the much higher percentage coverage in protected areas.

TABLE 5 The main threats to the white-lipped peccary, with the area (and percentage) of the current range affected.

\begin{tabular}{lc}
\hline Threat & Affected area, $\mathrm{km}^{2}(\%)$ \\
\hline $\begin{array}{l}\text { Habitat } \\
\text { transformation/ } \\
\text { deforestation }\end{array}$ & $2,816,535(39)$ \\
Hunting & \\
Human-population & $2,277,963(32)$ \\
growth & $2,244,864(31)$ \\
Resource extraction & \\
Livestock ranching & $1,456,439(20)$ \\
Small population & $1,273,168(18)$ \\
Low connectivity & $599,754(8)$ \\
Other & $337,714(5)$ \\
Disease & $290,346(4)$ \\
No threat & $36,888(0.5)$ \\
\hline
\end{tabular}

\section{Discussion}

\section{Conservation status}

Conservation of wide-ranging species such as the whitelipped peccary requires a broad geographical perspective. Our synthesis of observations across the range of this species $\left(>14,097,695 \mathrm{~km}^{2}\right)$ shows that it has lost $>21 \%$ of its range since the beginning of the 2oth century. Major range reductions have occurred in Central America, Mexico, north-west South America, the arid region of north-east Brazil and along the species' southern limit in Argentina. The species is now extinct in El Salvador and its range has been reduced by $>60 \%$ in several other countries. Brazil, Peru and Bolivia are particularly important for this species; combined, they account for $>78 \%$ of the species' current range.

White-lipped peccary populations in more xeric environments have been particularly affected. For example, $25 \%$ of

TABLE 6 Number (and percentage) and area (and percentage) of white-lipped peccary conservation units categorized by conservation status (see text for details).

\begin{tabular}{lcc}
\hline Conservation status & No. (\%) & Area (\%) \\
\hline High & $19(33)$ & $3,524,988(65)$ \\
Medium & $26(46)$ & $1,796,911(33)$ \\
Low & $8(14)$ & $63,415(1)$ \\
No information & $4(7)$ & $5,089(0.1)$ \\
Total & 57 & $5,390,403$ \\
\hline
\end{tabular}


TABLE 7 Number, percentage, mean area and total area of peccary conservation units containing different herd and population sizes of white-lipped peccary.

\begin{tabular}{|c|c|c|c|c|}
\hline No. of individuals & No. & $\%$ & Mean area $\left(\mathrm{km}^{2}\right)$ & Total area $\left(\mathrm{km}^{2}\right)$ \\
\hline \multicolumn{5}{|c|}{ Estimated herd size } \\
\hline$>20$ & 28 & 49 & 155,424 & $3,131,743$ \\
\hline $11-20$ & 1 & 2 & 802 & 802 \\
\hline $5-10$ & 7 & 12 & 6,901 & 44,153 \\
\hline$<5$ & 1 & 2 & 3,863 & 3,863 \\
\hline No information & 20 & 35 & 49,278 & $2,209,841$ \\
\hline \multicolumn{5}{|c|}{ Estimated population size } \\
\hline$>5,000$ & 11 & 19 & 248,769 & $2,736,459$ \\
\hline $1,001-5,000$ & 19 & 33 & 118,999 & $2,260,981$ \\
\hline $500-1,000$ & 6 & 10 & 29,418 & 176,509 \\
\hline$<500$ & 8 & 14 & 2,347 & 14,622 \\
\hline No information & 13 & 23 & 15,206 & 201,832 \\
\hline
\end{tabular}

the overall range loss has occurred in the Caatinga/Xeric Forest eco-geographical region of north-east Brazil, where the species persists in a fragmented area of $<20,000 \mathrm{~km}^{2}$. Other eco-geographical regions with poor prognoses for population survival are the Pampas/Herbaceous Lowland Grassland, where the peccary persist in $<900 \mathrm{~km}^{2}$, and the Cerrado/Tropical Dry Forest, where only $18 \%$ of the area is in peccary conservation units and most of the remaining area has populations rated with low and medium probabilities of survival. However, prospects for the species survival are better in other eco-geographical regions, including the Upper Amazon, which contains the largest contiguous range polygon and where this species is judged to have a medium to high probability of survival across the entire area.

\section{Could the white-lipped peccary become ecologically extinct?}

Given the vast range loss, representing local extinctions, and reductions in many of the remaining populations, we are concerned that this major ecosystem architect of the Neotropics could become ecologically extinct. Although $70 \%$ of the peccary conservation units are considered to have stable populations, only $1 \%$ of the species' range was assessed as completely free from anthropogenic threat (not considering effects of climate change such as changes in rainfall). Habitat loss and hunting accounts for threats in $70 \%$ of

TABLE 8 Number (and percentage) of peccary conservation units, and their area (and percentage) exhibiting increasing, decreasing or stable population trends or for which there is no information.

\begin{tabular}{lcr}
\hline Population trend & No. (\%) & Area, $\mathrm{km}^{2}(\%)$ \\
\hline Increasing & $1(2)$ & $3,153(0.1)$ \\
Decreasing & $24(42)$ & $1,326,735(25)$ \\
Stable & $16(28)$ & $3,757,551(70)$ \\
No information & $16(28)$ & $302,964(6)$ \\
Total & 57 & $5,390,403$ \\
\hline
\end{tabular}

TABLE 9 Number (and percentage) of peccary conservation units under four types and intensity of hunting.

\begin{tabular}{|c|c|c|c|c|}
\hline \multirow{2}{*}{$\begin{array}{l}\text { Intensity } \\
\text { of hunting }\end{array}$} & \multicolumn{4}{|c|}{ Hunting type } \\
\hline & Subsistence & Opportunistic & Commercial & Sport \\
\hline High & $16(28)$ & $9(16)$ & $2(3)$ & $3(5)$ \\
\hline Medium & $24(42)$ & $28(49)$ & $20(35)$ & $14(25)$ \\
\hline None & $2(4)$ & $3(5)$ & $14(25)$ & $17(30)$ \\
\hline No information & $15(26)$ & $17(30)$ & $21(37)$ & $23(40)$ \\
\hline
\end{tabular}

the species' range, in agreement with previous studies (Fragoso, 1997; Cullen et al., 2000; Peres, 2001; Altrichter \& Boaglio, 2004; Reyna-Hurtado, 2009; Reyna-Hurtado et. al, 2009). A serious problem is the low effectiveness of protection for this species across its range. Although partial protection exists in $60 \%$ of the combined area of all peccary conservation units, in only $9 \%$ of this area (the key strongholds for this species' survival) does the white-lipped peccary appear to be adequately protected. Furthermore, although $30 \%$ of the total peccary conservation unit area is within IUCN protected area categories, in only $20 \%$ of this area is protection considered effective for the species. These findings underline the limitations of protected areas in Latin America for conserving large, wide-ranging species.

Any ecological extinction of the white-lipped peccary could have far reaching consequences given their role as ecological architects and ecosystem engineers in Neotropical forests (Beck, 2008; Keuroghlian \& Eaton, 2009; Beck et al., 2010). At high densities this species may have the highest total vertebrate species biomass, reaching up to $230 \mathrm{~kg} \mathrm{~km}^{-2}$ (Peres, 1996; Silman et al., 2003). Many ecosystem changes have been documented following local extinction of the white-lipped peccary (Silman et al., 2003; Wyatt \& Silman, 2004). The species consumes $>144$ plant species of 38 families, in addition to a variety of invertebrates, bird eggs, fishes, snakes, frogs and small mammals (Bodmer, 1989; Altrichter et al., 2001; Beck, 2005, 2006; Keuroghlian \& Eaton, 2008a; Desbiez et al., 2009). It is an important seed predator and, together with tapirs, is the only species that can crush many hard nuts (Kiltie, 1981, 1982; Beck, 2005; Keuroghlian \& Eaton, 2008a). It also disperses many smallseeded species (e.g. Ficus spp.; Altrichter et al., 1999; Beck, 2005) and mycorrhizae spores, crucial to maintaining

TABLE 10 The percentage of peccary conservation units under various deforestation and resource-extraction regimes

\begin{tabular}{llc}
\hline Regime & Deforestation (\%) & Resource-extraction (\%) \\
\hline High & 19 & 4 \\
Medium & 37 & 58 \\
Low & 14 & 0 \\
None & 5 & 12 \\
No information & 25 & 26 \\
\hline
\end{tabular}


TABLE 11 Estimated area $\left(\mathrm{km}^{2}\right)$ under different degrees of effectiveness of protection within peccary conservation units by various landtenure types and IUCN (1994) categories.

\begin{tabular}{|c|c|c|c|c|c|}
\hline & \multicolumn{4}{|c|}{ Effectiveness of protection within peccary conservation units } & \multirow[b]{2}{*}{ Total (\%) } \\
\hline & Total & Partial & None & No information & \\
\hline \multicolumn{6}{|c|}{ Land-tenure type } \\
\hline Private & 543 & 319,230 & 302,533 & 117,556 & $739,862(15)$ \\
\hline Communal & 0 & $1,443,623$ & 12,108 & 184,885 & $1,640,615(32)$ \\
\hline Undefined & 80,511 & 0 & 22,228 & 636,614 & $739,353(15)$ \\
\hline Other* & 182,708 & 93,341 & 10,129 & 199,096 & $485,274(10)$ \\
\hline \multicolumn{6}{|c|}{ IUCN category } \\
\hline I & 5,998 & 485,970 & 3,654 & 0 & $495,622(10)$ \\
\hline II & 149,625 & 583,074 & 2,875 & 93,186 & $828,760(16)$ \\
\hline III & 0 & 0 & 0 & 14,617 & $14,617(0.3)$ \\
\hline IV & 28,063 & 84,175 & 0 & 0 & $112,238(2)$ \\
\hline $\mathrm{V}$ & 0 & 0 & 6,919 & 844 & $7,763(0.3)$ \\
\hline Total (\%) & $447,448(9)$ & $3,009,412(59)$ & $360,445(7)$ & $1,246,797(25)$ & $5,064,102$ \\
\hline
\end{tabular}

${ }^{*}$ Mainly indigenous reserves and state lands

symbiotic relationships with many plant species (H. Beck, unpubl. data). Trampling by large groups of foraging whitelipped peccary can affect seedling densities (Asquith et al., 1997; Roldan \& Simonetti, 2001; Keuroghlian \& Eaton, 2009). Given its high biomass and diverse consumption of fruit and seeds, this species may regulate populations of numerous terrestrial frugivores via exploitative and interference competition (Beck, 2005, 2006; Keuroghlian \& Eaton, 2008a). White-lipped peccary are also important prey for jaguars and pumas (Kiltie \& Terborgh, 1983; Aranda, 2002). Increased carnivore-livestock conflicts have been documented where white-lipped peccaries have disappeared, presumably because of prey-switching by carnivores (Azevedo \& Conforti, 2008; Cavalcanti \& Gese, 2010).

However, we do not know how these numerous ecological interactions with other species and the abiotic environment change with variations in white-lipped peccary population density. Such information is required for a full examination of whether the white-lipped peccary is threatened with ecological extinction. The data and analyses presented here do, nevertheless, demonstrate major contractions in the species' range, which suggest declines, or at least modifications, of the various ecological roles of the white-lipped peccary in places where the species is now absent.

\section{Conservation of the white-lipped peccary}

The size of peccary conservation units and the risk of deforestation and hunting appear to be critical factors for the survival of this species. White-lipped peccaries use habitats non-randomly, underlining their need for a variety of ecosystem types and their associated fruiting species (Keuroghlian \& Eaton, 2008a; Lee \& Peres, 2008; Galetti et al., 2009; Keuroghlian \& Eaton, 2009). Genetic studies in the Brazilian Pantanal have demonstrated that the white-lipped peccary must be managed at the scale of landscapes and metapopu- lations (Biondo et al., 2008). Recent data indicate a low degree of genetic differentiation between two populations 80 $\mathrm{km}$ apart (Biondo et al., 2010). Individual groups also range over very large areas (from $<40 \mathrm{~km}^{2}$ to $120-200 \mathrm{~km}^{2}$; Fragoso, 1998; Carrillo et al., 2002; Reyna-Hurtado et al., 2010). Accordingly, conservation efforts need to focus on landscape conservation of large, continuous and ecologically intact areas containing a mosaic of habitat types, as defined by the peccary conservation units.

The range-wide assessment presented here will allow national-level conservation planners to appreciate the range of major habitat types utilized by the white-lipped peccary. Conservation action for this species, primarily habitat protection and improved management of hunting (including total prohibition in some places), and policy changes, are urgently required (Galetti et al., 2009). Our findings emphasize, in particular, the need to focus on the conservation of the ecologically distinct populations in dry forests, savannahs and shrublands.

We identified several regions where the distribution and conservation status of the white-lipped peccary is unknown. In addition, even though the major part of this species' distribution is in the Tropical Moist Lowland Forest of the Upper Amazon and the adjoining Cerrado eco-geographical regions, status and ecological studies in these areas are sparse, with a density of detection locality points of $<_{1}$ per 23,000 $\mathrm{km}^{2}$ (Taber et al., 2008). These geographies should be research priorities in future studies.

\section{Acknowledgements}

This work was supported by a grant from the Gordon and Betty Moore Foundation to the Wildlife Conservation Society, which also provided logistic support. The latter's Landscape Ecology and Geographic Analysis Program guided the data collection and geographical information 
system analyses. We thank Karen Minkowski from that programme. The Liz Claiborne and Art Ortenberg Foundation and the Wildlife Trust also provided financial and other support. We especially thank the 41 peccary specialists and other colleagues (Appendix 1) who shared their original data: such unswerving generosity is key for conservation.

\section{References}

Alexander, R.R. (2000) Modelling species extinction: the case for non-consumptive values. Ecological Economics, 35, 259-269.

Altrichter, M. \& Boaglio, G.I. (2004) Distribution and relative abundance of peccaries in the Argentine chaco: associations with human factors. Biological Conservation, 116, 217-225.

Altrichter, M., Carrillo, E., Saenz, J. \& Fuller, T. (2001) White-lipped peccary (Tayassu pecari) diet and fruit availability in a Costa Rican rain forest. Revista de Biología Tropical, 49, 1105-1114.

Altrichter, M., Sáenz, J. \& Carrillo, E. (1999) Chanchos cariblancos (Tayassu pecari) como predadores y dispersores de semillas en el Parque Nacional Corcovado, Costa Rica. Brenesia, 52, 53-59.

Anon. (1995) A Regional Analysis of Geographic Priorities for Biodiversity Conservation in Latin America and the Caribbean. Biodiversity Support Program, Conservation International, The Nature Conservancy, Wildlife Conservation Society, World Resources Institute, and WWF, Washington, DC, USA.

ARAND A, M. (2002) Importancia de los pecaríes para la conservación del jaguar en México. In El Jaguar en el Nuevo Mileno (eds R.A. Medellin, C. Equihua, C.L.B. Chetkiewicz, P.G. Crawshaw, Jr, A. Rabinowitz, K.H. Redford et al.), pp. 101-106. Fondo de Cultura Económica, Ediciones Científicas Universitarias, Universidad Nacional Autónoma de México, and Wildlife Conservation Society, México.

Asquith, N.M., Wright, S.J. \& Clauss, M.J. (1997) Does mammal community composition control recruitment in neotropical forests? Evidence from Panama. Ecology, 78, 941-946.

Azevedo, F.C.C. \& Conforti, V.A. (2008) Decline of peccaries in a protected subtropical forest of Brazil: toward conservation issues. Mammalia, 72, 82-88.

BECK, H. (2005) Seed predation and dispersal by peccaries throughout the Neotropics and its consequences: a review and synthesis. In Seed Fate: Predation, Dispersal and Seedling Establishment (eds P.M. Forget, J.E. Lambert, P.E. Hulme \& S.B. Vander Wall), pp. 77-115. CABI Publishing, Wallingford, UK.

BЕСK, H. (2006) A review of peccary-palm interactions and their ecological ramifications across the Neotropics. Journal of Mammalogy, 87, 519-530.

B Еск, H. (2008) Tropical ecology. In Encyclopedia of Ecology (eds S.E. Jorgensen \& B. Fath), pp. 3616-3624. Elsevier B.V., Oxford, UK.

Beck, H., Thebpanya, P. \& Filiaggi, M. (2010) Do Neotropical peccary species (Tayassuidae) function as ecosystem engineers for anurans? Journal of Tropical Ecology, 26, 1-8.

Biondo, C., Keuroghlian, A., Gongora, J. \& Miyaki, C.Y. (2010) Population genetic structure and dispersal in white-lipped peccaries (Tayassu pecari) from the Brazilian Pantanal. Journal of Mammalogy, 92, 267-274.

Biondo, C., Keuroghlian, A. \& Miyaki, C.Y. (2008) Analysis of genetic variability and population genetics structure of whitelipped peccaries (Tayassu pecari) from the Pantanal (MS, Brazil): preliminary results. Suiform Soundings, 8, 28-31.
BLAKE, S. \& HEDGES, S. (2004) Sinking the flagship: the case of forest elephants in Asia and Africa. Conservation Biology, 18, 1191-1202.

Bodmer, R.E. (1989) Frugivory in Amazonian Artiodactyla: evidence for the evolution of the ruminant stomach. Journal of Zoology, 219, $457-467$.

Bodmer, R.E., Sowls, L.K. \& Taber, A.B. (1993) Economic importance and human utilization of peccaries. In Status Survey and Conservation Action Plan: Pigs, Peccaries and Hippos: Status Survey and Conservation Action Plan (ed. W.L.R. Oliver), pp. 2936. IUCN/Species Survival Commission, Gland, Switzerland.

Carrillo, E., Saenz, J.C. \& Fuller, T.K. (2002) Movements and activities of white-lipped peccaries in Corcovado National Park, Costa Rica. Biological Conservation, 108, 317-324.

Cavalcanti, S.M.C. \& Gese, E.M. (2010) Kill rates and predation patterns of jaguars (Panthera onca) in the southern Pantanal, Brazil. Journal of Mammalogy, 91, 722-736.

Cullen, Jr, L., Bodmer, R.E. \& Valladares-Padua, C. (2000) Effects of hunting in habitat fragments of the Atlantic forests, Brazil. Biological Conservation, 95, 49-56.

Desbiez, A.L.J., Santos, S.A., Keuroghlian, A. \& Bodmer, R.E. (2009) Niche partitioning among white-lipped peccaries (Tayassu pecari), collared peccaries (Pecari tajacu), and feral pigs (Sus scrofa). Journal of Mammalogy, 90, 119-128.

Dinerstein, E., Olson, D.M., Graham, D.J., Webste, A.L., Primm, S.A., Bookbinder, M.P. et al. (1995) A Conservation Assessment of the Terrestrial Ecoregions of Latin America and the Caribbean. The World Bank, Washington, DC, USA.

Eisenberg, J.F. \& Redford, K.H. (2000) Mammals of the Neotropics: The Central Neotropics: Ecuador, Peru, Bolivia, Brazil. University of Chicago Press, Chicago, USA.

Estes, J.A., Duggins, D. \& Rathburn, G. (1989) The ecology of extinctions in kelp forest communities. Conservation Biology, 3, 252-264.

Fragoso, J.M.V. (1997) Desapariciones locales del baquiro labiado (Tayassu pecari) en la Amazonia: migración, sobre-cosecha o epidemia. In Manejo de Fauna Silvestre en la Amazon (eds T.G. Fang, R.E. Bodmer, M.H. Aquino \& M. Valqui), pp. 309-312. UNAP, University of Florida, UNDP/GEF and the Instituto de Ecologia, La Paz, Bolivia.

FRAGOSO, J.M.V. (1998) Home range and movement patterns of white-lipped peccary (Tayassu pecari) herds in the Northern Brazilian Amazon. Biotropica, 30, 458-469.

Fragoso, J.M.V. (1999) Perception of scale and resource partitioning by peccaries: behavioral causes and ecological implications. Journal of Mammalogy, 80, 993-1003.

Fragoso, J.M.V. (2004) A long-term study of white-lipped peccary (Tayassu pecari) population fluctuation in Northern Amazonia. In People in Nature: Wildlife Conservation in South and Central America (eds K.M. Silvius, R.E. Bodmer \& J.M.V. Fragoso), pp. 286-296. Columbia University Press, New York, USA.

Freitas, T.P.T., Keuroghlian, A. Eaton, D. P., De Freitas, E. B., Figueiredo, A. Nakazato, L. et al. (2010). Prevalence of Leptospira interrogans antibodies in free-ranging Tayassu pecari of the southern Pantanal, Brazil, an ecosystem where wildlife and cattle interact. Tropical Animal Health and Production, 42, $1695-1703$.

Galetti, M., Giacomini, H.C., Buenos, R.S., Bernardo, C.S.S., Marques, R.M., Bovendorp, R.S. et al. (2009) Priority areas for the conservation of Atlantic forest large mammals. Biological Conservation, 142, 1229-1241.

Herrera, H.M., Abreu, U.G.P., Keuroghlian, A., Freitas, T.P. \& JANSEN, A. (2008) The role played by sympatric collared peccary (Tayassu tajacu), white-lipped peccary (Tayassu pecari), and feral pig (Sus scrofa) as maintenance hosts for Trypanosoma 
evansi and Trypanosoma cruzi in a sylvatic area of Brazil. Parasitology Research, 103, 619-624

IUCN (1994) Guidelines for Protected Area Management Categories. IUCN, Gland, Switzerland.

IUCN/SSC (2008) Strategic Planning for Species Conservation: A Handbook. Version 1.o. IUCN Species Survival Commission, Gland, Switzerland.

Keuroghlian, A. \& Eaton, D.P. (2008a) Importance of rare habitats and riparian zones in a tropical forest fragment: preferential use by Tayassu pecari, a wide-ranging frugivore. Journal of Zoology, 275, 283-293.

Keuroghlian, A. \& Eaton, D.P. (2008b) Fruit availability and peccary frugivory in an isolated Atlantic forest fragment: effects on peccary ranging behavior and habitat use. Biotropica, 40, 6270.

Keuroghlian, A. \& Eaton, D.P. (2009) Removal of palm fruits and ecosystem engineering in palm stands by white-lipped peccaries (Tayassu pecari) and other frugivores in an isolated Atlantic Forest fragment. Biodiversity and Conservation, 18, 17331750 .

Kiltie, R.A. (1981) Stomach contents of rain forest peccaries (Tayassu tajacu and T. pecari). Biotropica, 13, 234-236.

Kiltie, R.A. (1982) Bite force as a basis for niche differentiation between rain forest peccaries (Tayassu tajacu and Tayassu pecari). Biotropica, 14, 188-195.

Kiltie, R.A. \& Terborgh, J. (1983) Observations on the behavior of rain forest peccaries in Peru: why do white-lipped peccaries form herds? Zeitschrift für Tierpsychologie, 62, 241-255.

Lee, A. \& Peres, C.A. (2008) Conservation value of remnant riparian forest corridors of varying quality for Amazonian birds and mammals. Conservation Biology, 22, 439-449.

March, I. (1993) The white-lipped peccary (Tayassu pecari). In Pigs, Peccaries, and Hippos: Status Survey and Conservation Action Plan (ed. W.L.R. Oliver), pp. 13-22. IUCN, Gland, Switzerland.

MEA (Millennium Ecosystem Assessment) (2005) Ecosystems and Human Well-being: Biodiversity Synthesis. World Resources Institute, Washington, DC, USA.

Novaro, A.J., Funes, M.C. \& Walker, R.S. (2000) Ecological extinction of native prey of a carnivore assemblage in Argentine Patagonia. Biological Conservation, 92, 25-33.

Oliver, W.L.R. (1993) Pigs, Peccaries, and Hippos: Status Survey and Conservation Action Plan. IUCN, Gland, Switzerland.

Parera, A. \& Erize, F. (2002) Los mamíferos de la Argentina y la Región Austral de Sudamérica. El Ateneo. Buenos Aires, Argentina.

Peres, C.A. (1996) Population status of white-lipped Tayassu pecari and collared peccaries T. tajacu in hunted and unhunted Amazonian forests. Biological Conservation, 77, 115-123.

Peres, C.A. (2001) Synergistic effects of subsistence hunting and habitat fragmentation on Amazonian forest vertebrates. Conservation Biology, 15, 1490-1505.

Redford, K.H., Amato, G., Baillie, J., Beldomenico, P., Bennett, E.L., Clumet, N. et al. (2010) What does it mean to successfully conserve a (vertebrate) species? BioScience, 61, 39-48.

Redford, K.H. \& EisenberG, J. (1992) Mammals of the Neotropics: The Southern Cone. Volume 2: Chile, Argentina, Uruguay, Paraguay. University of Chicago, Chicago, USA.

Redford, K.H. \& Feinsinger, P. (2001) The half-empty forest: sustainable use and the ecology of interactions. In Conservation of Exploited Species (eds J.D. Reynolds, G.M. Mace, K.H. Redford \& J.G. Robinson), pp. 370-399. Cambridge University Press, Cambridge, UK.
Reyna-Hurtado, R. (2007) Social ecology of the white-lipped peccary (Tayassu pecari) in Calakmul forest, Campeche, Mexico. $\mathrm{PhD}$ thesis, University of Florida. Gainesville, USA.

Reyna-Hurtado, R. (2009) Conservation status of the whitelipped peccary (Tayassu pecari) outside the Calakmul Biosphere Reserve in Campeche, Mexico: a synthesis. Tropical Conservation Science, 2, 159-172.

Reyna-Hurtado, R., Naranjo, E., Chapman, C.A. \& Tanner, G.W. (2010) Hunting patterns, population density, group size, and conservation of the white-lipped peccary (Tayassu pecari) in the Calakmul region of Mexico. Oryx, 44, 88-96.

Reyna-Hurtado, R.E., Rojas-Flores, E. \& Tanner, G.W. (2009) Home range and habitat preferences of white-lipped peccary groups (Tayassu pecari) in a seasonal tropical forest of the Yucatan Peninsula, Mexico. Journal of Mammalogy, 90, 1199-1209.

Reyna-Hurtado, R., Taber, A., Altrichter, M., Fragoso, J., Keuroghlian, A. \& Beck, H. (2008) Tayassu pecari. In IUCN Red List of Threatened Species v. 2010.4. Http://www.iucnredlist. org [accessed 3 May 2011].

Reyna-Hurtado, R. \& Tanner, G.W. (2007) Ungulate relative abundance in hunted and non-hunted sites in Calakmul Forest (southern Mexico). Biodiversity and Conservation, 16, 743-757.

Roldan, A.I. \& Simonetti, J.A. (2001) Plant-mammal interactions in tropical Bolivian forests with different hunting pressures. Conservation Biology, 15, 617-623.

Sanderson, E.W., Redford, K.H., Chetkiewicz, C.L.B., Medellin, R.A., Rabinowitz, A.R., Robinson, J.G. et al. (2002b) Planning to save a species: the jaguar as a model. Conservation Biology, 16, 58-72.

Sanderson, E.W., Redford, K.H., Vedder, A., Ward, S.E. \& Coppolillo, P.B. (2002a) A conceptual model for conservation planning based on landscape species requirements. Landscape and Urban Planning, 58, 41-56.

Sanderson, E.W., Redford, K.H., Weber, B., Aune, K., Baldes, D., Berger, J. et al. (2008) The ecological future of the North American bison: conceiving long-term, large-scale conservation of wildlife. Conservation Biology, 22, 252-266.

SeCretariat of the Convention on Biological Diversity (2010) Global Biodiversity Outlook 3. Montreal, Canada.

Silman, M.R., Terborgh, J.W. \& Kiltie, R.A. (2003) Population regulation of a dominant rain forest tree by a major seed predator. Ecology, 84, 431-438.

Soule, M., Estes, J.A., Berger, J. \& Martinez del Rio, C. (2003) Ecological effectiveness: conservation goals for interacting species. Conservation Biology, 17, 1238-1250.

Sow LS, L.K. (1997) Javelinas and Other Peccaries: Their Biology, Management, and Use. 2nd ed. Texas A\&M University Press, College Station, USA.

Stearman, A.M. (1992) Neotropical hunters and their neighbors: Sirionó, Chimane and Yuquí hunting on the Bolivian frontier. In Conservation of Neotropical Forest (eds K. Redford \& C. Padoch), pp. 108-128. Columbia University Press, New York. USA.

Taber, A., Chalukian, S.C., Altrichter, M., Minkowski, K., Lizárraga, L., Sanderson, E., et al. (2008) El Destino de los arquitectos de los bosques Neotropicales: Evaluación de la distribución y el estado de conservación de los Pecaries Labiados y los Tapires de Tierras Bajas. Grupo Especialista de la CSE/UICN en Cerdos, Pecaríes \& Hipopótamos; Grupo Especialista de la CSE/ UICN en Tapires, Wildlife Conservation Society and Wildlife Trust, New York, USA.

Thorbjarnarson, J., Mazzotti, F., Sanderson, E., Buitrago, F., Lazcano, M., Minkowski, K. et al. (2006) Regional habitat conservation priorities for the American crocodile. Biological Conservation, 128, 25-36. 
Woodroffe, R. \& Ginsberg, J. (1998) Edge effects and extinction of populations inside protected areas. Science, 280, 2126-2128.

Wyatt, J.L. \& Silman, M.R. (2004) Distance-dependence in two Amazonian palms: effects of spatial and temporal variation in seed predator communities. Oecologia, 140, 26-35.

\section{Appendices}

The appendices for this article are available online at http:// journals.cambridge.org

\section{Biographical sketches}

Mariana Altrichter works to conserve peccaries and studies their importance in subsistence economies of northern Argentina and
Costa Rica. ANDREW TABER is a biologist working to reconcile tradeoffs between conservation and development across the tropics. HARALD BECK's research focuses on non-trophic and trophic interactions of large mammal species and the resulting ecological consequences for the ecosystem. RAFAeL REYNA-HuRTaDo's research focus is on movement ecology and conservation of threatened tropical ungulates and primates of southern Mexico. LEONIDAS LIZARRAGA is a geographical information system specialist studying spatial-temporal human and ecological relationships between protected areas and their surroundings. Alexine Keuroghlian's research includes using white-lipped peccary ecology and genetic data to define ecological corridors in the Pantanal and its highland plateaus. ERIC W. SANDERSON is a landscape ecologist interested in developing sustainable relationships between people and nature at all scales. 